\title{
Employment opportunities in LIS field: A content analysis of positions advertised
}

\author{
Nitesh V Chore \\ Librarian, Vinayak Vidnyan Mahavidyalaya, Nandgaon $\{\mathrm{KH}\}$ Dist-Amravati, Maharashtra, India \\ *Corresponding Author: Nitesh V Chore \\ Email: niteshchore123@gmail.com
}

\begin{abstract}
The new era Librarian will become the guardian of digital information and will be the vehicle to preserve democratic access to information. The evaluation, acquisition, organization, sharing and distribution of information in all formats, including books, periodicals, online services such internal works product document and database resources in an integral parts of works. Therefore adequate knowledge of IT and its application in libraries with a positive attitude can make the real difference between the real and desired situation. Hence all the professionals should be IT skilled persons.
\end{abstract}

Keywords: Employment opportunities in LIS, LIS Profession.

\section{Introduction}

The advancement of technology the libraries are moving towards digital resources, which are found to be less expensive and more helpful for easy access. There are helpful especially to distant learners who have limited time to access the libraries from outside by dial up access by the commonly available electronic resources mainly CD-ROMs, OPACs, and Internet etc., which are replacing the print media.

India has one of the largest educational systems in the world. There were only 20 universities and 500 colleges at the time of Independence. At present there are 369 Universities comprising 222 State Universities, 20 Central Universities, 109 Deemed Universities,5 Institutions established under States legislations and 13 Institutes of national importance established by Central Legislation. Four new Central University Acts are in the process of being brought in to force. In addition, there are 18,064 colleges including 1902 women's colleges. At the beginning of the academic year 2006-07, the total number of students enrolled in the universities and colleges was reported to be 110.28 lakhs; 14.27 lakhs (12.94\%) in University Departments and 96.01 lakhs $(87.06 \%)$ in affiliated colleges (Annual Report, Ministry of Human Resource Development 2006-2007). In spite of these facilities higher education in India is not accessible to more that six percent of the population. To meet the growing demand for higher education, the number of distance education programmes are growing up in India. The growth and expansion of distance education programmes have generated considerable interest in student support services in general, and library and information services in particular. LIS education in India is currently passing through a turning point and has become a fast developing subject with a multidisciplinary approach. Today LIS education not only includes the library specific subject but it also has been extended to subjects like computer application, statistics, information science, management studies and operation research. With the changing scenario modern librarianship has become a profession with a diversity of opportunities and challenges for LIS students and professionals.

The focus of LIS education is to develop competent and skilled human resources to meet changing requirements. The focus of LIS education is to develop competent and skilled human resources to meet the changing requirements. Many evolutionary changes have taken place in the information market place from Dewey school of library economy to $21^{\text {st }}$ century information science school ${ }^{2}$. According to Sinha and Pandey, "LIS professional are expected to be academics of higher order with competence of higher order with competence to work in a hypertext, networked, digital environment. Hence, the LIS Education should impart the learners, the necessary skills to gain employment upon graduation and to develop the vision and understanding to help them cope better with the rapidly changing world." But Raghavan and Agrawal found that there is a mismatch between products of professional education programs in library and information science and the requirements of job market.

This research explores data librarian job advertisements found through multiple online job boards in the United States academic libraries. The purpose of doing this exploration is to move towards discovering core competencies for data librarianship and finding emerging trends in skill requirements, job responsibilities, and qualifications needed to be a data librarian. The results of this preliminary study should be a starting point in aligning LIS curricula to meet the needs of prospective employers, along with highlighting the expanding boundaries of the LIS profession.

The new era Librarian will become the guardian of digital information and will be the vehicle to preserve democratic access to information. The evaluation, acquisition, organization, sharing and distribution of information in all formats, including books, periodicals, online services such internal works product document and database resources in an integral parts of works. Therefore adequate knowledge of IT and its application in libraries with a positive attitude can make the real difference between the real and desired situation. Hence all the professionals should be IT skilled persons.

1. Certificate course in Library and Information Science (C.Lib.Sc)

2. Diploma in Library and Information Science 
3. B.Lib.Sc. /BLIS (Bachelor Degree in Library and Information Science)

4. M.Lib.Sc. /MLIS (Master Degree in Library and Information Science)

5. PGDLAN (Post Graduate Diploma in Library Automation and Networking)

6. M.Phil (Master of Philosophy) in Library and Information Science

7. Ph.D (Doctor of Philosophy) in Library and Information Science

8. D.Litt in Library and Information Science

\section{The objectives of the study are:}

1. To find out the job advertisement trends in library and information science in India;

2. To assess the job advertisement by category of job, type of employer and state in which the jobs are advertised; and

3. To examine the essential qualifications and professional skills required to fulfill the demands of employer while recruiting LIS professionals.

4. To study the LIS job advertisements applying various study criteria like Month wise, State wise, Source wise, Category (Reserved / Unreserved; Teaching/NonTeaching) wise, Nature (Permanent/Temporary) wise, Level wise etc;
5. To present the current status of job opportunities for library and information science professionals at the national level in general;

6. To understand essential and desirable competencies, and other skills that employers advertise for the various positions of jobs for fresh LIS Graduates and PostGraduates and working LIS Professionals.

\section{Scope of the study}

The newspaper Times of India, Hitwad, and Employment News weekly due to its popularity in India has been used in this study for content analysis of job advertisements related to LIS field. The Times Group publishes total 14 editions in the country. Four editions of The Times of India (Mumbai, Ahmadabad, Chennai and Delhi) for the year 2017-2020 . Were selected for the study. The information gathered regarding LIS job advertisements from the four editions included date of advertisement, source of advertisement, nature of position, essential qualification required for the job, minimum year of experience required for the job, types of organization, state advertising job positions, additional qualification (skills) required for job and age limit prescribed for the post.

Table 1: Distribution of Posts

\begin{tabular}{|c|l|l|}
\hline S. No & \multicolumn{1}{|c|}{ Name of Post } & \multicolumn{1}{|c|}{ Number of Posts } \\
\hline 1. & Librarian & 101 \\
\hline 2. & Assistant Librarian & 13 \\
\hline 3. & Library Attendant & 59 \\
\hline 4. & Library Assistant & 43 \\
\hline 5. & Library Info Assistant & 77 \\
\hline & Total posts & 293 \\
\hline
\end{tabular}

In the Table 1 there is a distribution of posts and number of posts advertised in the studied newspapers. For Librarian post maximum number of posts is advertised. Total posts advertised are 293.

Table 2: Distribution of Posts in Newspaper

\begin{tabular}{|c|c|c|c|c|c|c|c|}
\hline & Newspapers & \multicolumn{6}{|c|}{ Name of Post } \\
\hline S. No. & & Librarian & $\begin{array}{c}\text { Assistant } \\
\text { Librarian }\end{array}$ & $\begin{array}{c}\text { Library } \\
\text { Attendant }\end{array}$ & $\begin{array}{c}\text { Library } \\
\text { Assistant }\end{array}$ & $\begin{array}{c}\text { Library Info } \\
\text { Assistant }\end{array}$ & Total \\
\hline 1. & Hitwad & 11 & 02 & 11 & 05 & 10 & 39 \\
\hline 2. & Indian Express & 27 & 04 & 19 & 14 & 20 & 84 \\
\hline 3. & Employment News & 63 & 07 & 29 & 24 & 47 & 170 \\
\hline & Total posts & 101 & 13 & 59 & 43 & 77 & 293 \\
\hline
\end{tabular}

In the table number 2 there is a distribution of posts and number of posts advertised in the studied newspapers .For Librarian post maximum number of posts is advertised. Total posts advertised are 293. Maximum number of posts are advertised in Employment news weekly.

Table 3: Year wise Distribution of Posts

\begin{tabular}{|c|c|c|c|c|c|c|}
\hline & Year wise & \multicolumn{5}{|c|}{ Name of Post } \\
\hline S. No. & & Librarian & $\begin{array}{c}\text { Assistant } \\
\text { Librarian }\end{array}$ & $\begin{array}{c}\text { Library } \\
\text { Attendant }\end{array}$ & $\begin{array}{c}\text { Library } \\
\text { Assistant }\end{array}$ & $\begin{array}{c}\text { Library Info } \\
\text { Assistant }\end{array}$ \\
\hline 1. & 2017 & 15 & 02 & 09 & 12 & 06 \\
\hline
\end{tabular}




\begin{tabular}{|c|c|c|c|c|c|c|}
\hline 2. & 2018 & 23 & 09 & 42 & 07 & 44 \\
\hline 3. & $2019-20$ & 63 & 02 & 08 & 24 & 27 \\
\hline & Total posts & 101 & 13 & 59 & 43 & 77 \\
\hline
\end{tabular}

In the table number 3 there is a distribution of posts and number of posts advertised in the studied newspapers year wise. For the year 2019-20 maximum number of posts is advertised. Total posts advertised are 293.

\section{Conclusion}

Out of total number of 293 posts, 123 posts do not mention any information in their advertisements regarding essential qualification. Some posts required either B.L.I.Sc or M.L.I.Sc to be an essential qualification. It was observed that there are some posts for which additional degrees like B.Ed., M.Phil. are also mentioned as essential qualifications along with B.L.I.Sc and M.L.I.Sc. The need to have qualified National Eligibility Test (NET) and State Eligibility Test (SET) candidate was highlighted in some posts.

Various additional skills such as good command over English, communication skills, managerial and organizational skills are preferred in addition to LIS degrees. It can be observed that one post specifically mentioned the need for knowledge of database as well as knowledge about a particular library management software. The results provide clear picture of essential skills and additional qualification desirable before applying for LIS posts. It can be seen that skills like proficiency in English, IT knowledge, communication skills; knowledge of local language is most preferred essential skills followed by knowledge of library management and managerial skills, organization skills and innovative approach required by LIS job industry. In addition to core library skills, today's LIS jobs also require other skills such as communication skills. Here, students coming from rural India and/or from nonEnglish- medium school background may not fare so well in the job market. Their options are confined to the sector speaking only the Indic language(s) they are comfortable with. Unfortunately, this aspect has so far been neglected by the curriculum development bodies. This language factor is perpetuating the gaps between the haves and have-nots in the field of LIS.

This study has found that library professionals are less satisfied with their jobs. So that care should be taken to improve the job-related factors like independence, variety, social status, good supervisory techniques, the point of moral values, authority towards work, utilization of ability of professionals, strong and favorable library policies, responsibility, promotion, recognition of innovative ideas/services and achievement. University LIS departments should take the appropriate steps to make LIS curriculum more practical oriented rather than theoretical. Library professionals should take the keen interest in acquiring the desirable ICT skills and knowledge. Apex bodies like UGC, AICTE, and NAAC should come up with the profound rules which give more weight-age to Library and Library profession. It is the good sign that corporate sector institutions/companies are showing interests in the establishment of libraries as their part functioning. But they are failing in treating the library professional important human resources like other professionals in the company.

\section{Conflict of Interest}

The authors declare that there are no conflicts of interest in this paper.

\section{Source of Funding}

None.

\section{References}

1. Annals of Library and Information Studies, vol 63,March 2016,pp,53-58

2. Overtoom C, Employability skills:an update.Eric Digest No.220 Available at: http://flies.eric.ed.gov/fulltext

3. Ameen K, Warrich NF, Employability skills of LIS graduates in Pakistan: needs and expectations. Libr Manag. 2011;32(3):209-24.

4. Sinha MK, Pandey B K, Status of job opportunities andemployment of library and information science professionalin India: an analysis of job advertisements, IOSR Journal

5. Raghavan K S and Agrawal N, Has the market place for information professionals changed? In Proceedings of the paper presented at Asia-Pacific Conference on Library \& Information Education \& Practice 2006 (A-LIEP 2006),

6. School of Communication and Information, Nanyang Technological University, Singapore, 3-6 April, 2006, p.409-15

7. Clyde LA. An instructional role for librarians: an overview and content analysis of job advertisements. Aus Acad Res Libr. 2002;33(3):150-67.

8. Deeken, J, Thomas D. Technical services job ads: Changes since 1995. College Res Libr. 2006;67(2):136-45.

9. Ewens T. Think Piece on CBE and Liberal Education (No. 1). CUE Project, Bowling Green State University. 1997.

10. Federer, L. Defining data librarianship: a survey of competencies, skills, and training. J Med Libr Assoc: JMLA. 2018;106(3):294.

How to cite: Chore NV. Employment opportunities in LIS field: A content analysis of positions advertised. IP Indian J Libr Sci Inf Technol. 2021;6(1):50-2. 